\title{
Institutional Aspects of Economic Growth: Assessing the Significance of Public Debt, Economic Governance and Industrial Competition
}

\author{
Mattheus F.A. Goosen* \\ Office of Research \& Graduate Studies, Alfaisal University, P.O. Box 50927, Riyadh, 11533, Saudi Arabia
}

\begin{abstract}
Institutional aspects of economic growth are critically reviewed with emphasis on the fiscal crisis facing the European Union (EU). In particular the importance of public debt, economic governance, and industrial competition are assessed, as well as the effectiveness of econometric models in forecasting economic growth. Likewise, the debate on whether political institutions cause economic growth, or whether, alternatively, growth and human capital accumulation lead to institutional improvement is discussed. Positive and negative institutional factors on economic growth will also be briefly debated.
\end{abstract}

Keywords: Institutions, economic growth, public debt, economic governance, industrial competition, catch-up, econometric models, EU.

\section{INTRODUCTION}

One of the most significant areas of research in economics is in trying to comprehend the factors that contribute to economic growth and political change, and how this affects the economic rise and decline of nations [1, 2]. The sovereign debt crisis has created enormous anguish in the European Monetary Union (EMU), and emergency measures are being used in order to try preventing its breakdown. Daianu [3] argues that there is need for a thorough reform of the governance structure of the European Union in conjunction with radical changes in the regulation and supervision of financial markets. Furthermore, Nobel Laureate Michael Spence cautions of the frictions that will arise when the world tries to accommodate both rapidlygrowing developing goliaths like India and China and slowgrowing developed nations like United States [4]. He goes on to describe the emergence of China as just part of an amazing catching-up process going on in the world.

There are economic philosophical differences (e.g. Keynesian versus Hayekian type of reasoning) in how to diagnose the EU crisis and how to cure the illness [5, 6]. The philosophies of John Keynes and Friedrich von Hayek, for instance, have dominated the economic scene for the last 60 years. Both of these leading economists had distinct ideas about economic freedom, concepts that were very clearly in opposition to each other. To Hayek, less government involvement meant added economic choice. He assumed that when individuals are free to select, the economy performs more efficiently. Furthermore, a decline in government spending with the aim of debt reduction and reducing the size of government would facilitate private sector investments, provide incentives for creative free enterprise and stimulate demand in industries, improve competition

*Address correspondence to this author at the Office of Research \& Graduate Studies, Alfaisal University, P.O. Box 50927, Riyadh, 11533, Saudi Arabia; Tel: +966 (0)53-294-1468; E-mail: mgoosen@alfaisal.edu through international trade and increase employment, thus creating more sustainable economic growth [5, 7-9]. On the other hand with Keynesian economics there is the belief that dynamic government involvement in the marketplace and monetary policy is the best way of guaranteeing economic progress and stability. The resurgence of Keynesian economics has been very contentious amongst professional economists. One point of view is that you cannot create sustainable growth through increased government spending called 'stimuli' and compensate with higher taxes. Although many economists, support Keynesian stimulus, others believe that higher government spending will not help the EU, nor the US economy recover from the recession [10, 11]. So we can ask the question, was John Keynes correct, can government fix the mass unemployment created by a fiscal decline? Or is that a risky misunderstanding as claimed by his opponent, Friedrich von Hayek? We can speculate that perhaps the answer or cure to the fiscal illness facing the EU as well as the US lies somewhere in between these two types of economic philosophies.

In this paper we will argue that the European Union (EU) debt crisis poses a serious risk to the economic and financial stability of the world. While the EU is trying to resolve its fiscal problems through financial regulation and crisis management, there is also a lot of uncertainty. The EU may need internal modifications in its governance structure, including tightening up on entry requirements. The key to solving these issues is to build up budget surpluses. While things will improve there is no quick fix. Furthermore, the projections of public debt ratios lead many experts to conclude that the path pursued by fiscal authorities in a number of industrial states is unsustainable. The consequences of taking on too much debt are that the process usually leads to default and insolvency. It makes no difference whether it is a business or a country. Far-reaching actions are required to limit the liabilities of governments. Likewise, we will discuss that a major vehicle to sustain economic expansion among nations lies in the industrial 
catch-up processes among frontrunners and stragglers that are born out of competition for enhanced performance. It will be shown that key elements in the catch-up process are the use of knowledge by emerging nations to mimic industries in order to save time and increase economic output; the need for nations to invest and save; and for states to sell their products to a worldwide market, rather than just domestically. Finally, we will join the debate on whether political institutions cause economic growth, or whether, alternatively, growth and human capital accumulation lead to institutional improvement. It will be shown that positive institutional factors on economic growth include consensual political systems that are flexible, a competitive environment with fiscal incentives that allows for continuous improvement in efficiency, industrial competition that allows for economic choices, and a well-developed educational system to help provide competent human capital for formal institutions such as courts. Negative institutional factors affecting economic growth are corruption due to fiscal and political decentralization resulting in stagnation due to reduced economic choices, autocrats or dictators that make poor policy choices, and high public debt in relation to a state's annual economic output.

There are a variety of institutional arrangements or determinants which influence the economic development process across countries [12-17]. These include political structure, political stability and relative size of government, civil liberties, property rights, and economic incentives. In addition, economic governance, public debt and industrial competition have been recognized as key factors in the economic success of nations. This knowledge is important, for example, to spur technological innovation in industries and countries, thus giving them a competitive edge. Abrams $\&$ Lewis [12], as a case in point, analyzed the growth rates for ninety nations from 1968 to 1987 . They found that political order as well as economic incentives and personal freedoms were significant determinants of growth. David Landes [18] in his book on "The Wealth and Poverty of Nations" argues that the history of the past 500 years should be Eurocentric. It is primarily the story of how expansionist Europeans and their ex colonies have grown very rich at the expense, to some degree, of the rest of the world. In fairness, Landes also argues that the history of the world from 500 to 1500 should be primarily Islamocentric.

In a study reported by Barro [6], it was shown that the economic growth rate was improved by higher initial schooling and life expectancy, lower fertility, lower government consumption, better maintenance of the rule of law, lower inflation and improved trade. In contrast to Abrams and Lewis [12] study, Barro [6] found that political freedom had only a weak effect on growth, but this effect was non-linear. For example, at low levels of political rights, an expansion of these rights stimulated economic growth. However, once a moderate amount of democracy had been attained, then a further increase reduced growth. In contrast, there was a strong positive effect of the standard of living on a country's inclination for democracy. North $[19,20]$ contends that institutions are central in creating property rights (e.g. real estate ownership), the rule of law, and competition. This provides stability or order which is essential for ensuring economic growth. His model of ordermaintaining systems has two poles or sets of political order with an autocratic regime (i.e. authoritarian political order) on one end and a democracy (i.e. consensual political order) on the other (Table 1) [20].

Table 1. Key Characteristics of Countries that are Able to Adapt to External Changes Quickly and Correctly Due to their Ability to Obtain a Consensus as a Result of their Flexible Culture (Adapted from North [20], Schlueter [14], Gottinger and Goosen [2])

\begin{tabular}{|ll|}
\hline - & $\begin{array}{l}\text { Employ common belief system to set up self-enforcing limits for } \\
\text { politicians }\end{array}$ \\
\hline - & $\begin{array}{l}\text { State should have an effective constitution that assigns citizen rights } \\
\text { and places limits on government decision making }\end{array}$ \\
\hline - & Well defined property and personal rights \\
\hline - & State officials must adhere to obligations and rights \\
\hline
\end{tabular}

North [20] remarks that economic markets tend to become inertial or complacent over time in the absence of a stimulus such as innovative institutional transformation. This is the same idea that democracies become less efficient at adapting to changing circumstances over time due to emergence of special interest groups (e.g. lobbyists) [13, 21]. However, a critical driving force for economic growth among states is a built-in and historically observable rivalry in stature, influence and economic performance that drives countries to get ahead or not to fall too far behind.

Cecchetti, et al. [22] notes that the monetary calamity that erupted in mid-2008 led to a sudden increase of public debt in many advanced economies; governments were required to re-capitalize banks, to take over a large part of the debts of failing financial institutions, and to introduce large stimulus programs to revive demand. The projections of public debt ratios lead Cecchetti et al. [22] to conclude that the path pursued by fiscal authorities in a number of industrial states is unsustainable.

Glaeser et al. [23] revisited the discussion over whether political institutions cause economic growth, or whether, alternatively, growth and human capital accumulation lead to institutional improvement. They found that most indicators of institutional quality used to establish the proposition that institutions cause growth, as outlined for example in North's and Olson's theories [24, 25] were constructed to be conceptually unsuitable for that purpose. Results suggested that human capital is a more basic source of growth than are the institutions, poor countries get out of poverty through good policies, often pursued by dictators, and subsequently improve their political institutions. As an example, in a recent interview Paul Kagame, the man who ended Rwanda's genocide in which $10 \%$ of the country's population was killed in just 100 days, was quoted as saying that as the country's President, he does not want foreign aid. He wants investment and free trade. "We believe in free enterprise, free market and competition. So we have to make sure there is a conducive environment for people to be creative and innovative," he told the interviewer [26]. In September 2009, the World Bank named Rwanda its "top reformer of business regulation," as the country soared to $67^{\text {th }}$ place from $143^{\text {rd }}$ the year before for ease of doing business." Many African leaders, however, have been 
criticized for hanging on to power well beyond their term limits. Whether Mr. Kagame will be one of the exceptions to this trend remains to be seen.

This paper critically reviews the institutional aspects of economic growth with emphasis on the fiscal crisis facing the European Union (EU). In particular the significance of public debt, economic governance and industrial rivalry are assessed as well as the utility of econometric models in forecasting economic growth. In addition, the debate on whether political institutions cause economic growth, or whether, alternatively, growth and human capital accumulation lead to institutional improvement is discussed.

\section{PUBLIC DEBT AND ECONOMIC GROWTH}

Concern over the sustainability of some EU countries' sovereign debt has continued to increase over the past few years. Cafisco [27] in examining the ways in which the monetary calamity caused a worsening of European debt-toGDP ratios, concluded that while things will improve there is no quick fix. He also explored which states required fiscal adjustment for debt sustainability. Greece and Portugal had unsustainable fiscal policies well before the 2008-2009 financial crisis; for Spain and Italy there is uncertainty about debt sustainability primarily due to worries about their future economic development. The key to solving these issues is to build up budget surpluses. However, this will take time.

Cottarelli [28] in a recent editorial asked the question about why markets have been worried about fiscal sustainability in the euro area and not in other advanced economies. The answer to this query is critical to understanding the policies needed to resolve the current crisis and also to help avoid future ones. The fiscal accounts of the United States, United Kingdom and Japan are as weak as those of some of the countries in the euro area. Ranking countries by their 2011 debt-to-GDP ratios, Cottarelli found Japan was first (i.e. the worst) and the USA was sixth (i.e. debt ratio $=102 \%$ ), just ahead of Portugal (i.e. debt ratio $=$ $107 \%$ ) and Ireland. So the crucial question is why are markets forgiving the fiscal negligence's of other advanced economies and not those of the euro area? Probable economic growth is perceived to be higher in the USA. This growth is critical for fiscal sustainability. We can reason however that high debt levels will hinder US growth. There is, however, a common denominator to the experiences of the USA, UK and Japan that is the massive intervention by their central banks to help prop up their fiscal systems. Cottarelli [28] concluded that reducing euro area weaknesses will require good monetary and fiscal policies designed to deal with the current crisis, such as the building up of budget surpluses, as similarly proposed by Cafisco [27]. Further progress is also needed in strengthening the fiscal union to avoid a future reappearance of comparable calamities.

Monetary crises are typically associated not only with severe economic slumps but also with a considerable worsening of fiscal situations; all of this resulting in an increase of public debt. In similar debt-to-GDP ratio studies performed by Cafisco [27] and Cottarelli [28], Furceri and Zdzienicka [29] measured the progression of the government gross debt-to-GDP ratio in the aftermath of banking crises from 1980 to 2006. Specifically, using a sample of 154 countries, the results of their exercise suggested that banking crises have produced a significant and long-lasting increase in the government debt-to-GDP ratio, with the effect being a function of the severity of the crisis. In particular, examining a set of structural and policy variables they found that larger increases in debt occurred in countries with worse initial fiscal positions and with a larger share of foreign debt. Countries were urged to avoid temporary stimuli since this would lead to increase permanently the debt levels. As an analogy, we can relate this situation to an individual consumer with an inadequate income using a credit card to buy food and to pay for accommodation rent. Assuming that the consumer, with a limited income, is only able to pay for the interest on the card balance, then the individual will be unable to pay off the balance itself. This is a non-sustainable situation. Most people eventually learn to avoid this fiscal irresponsibility; they learn to make good policy decisions.

Japan has been living with a public debt ratio of over $150 \%$ without any adverse effect on its cost. So it is possible that investors will continue to put strong faith in industrial countries' ability to repay, and that worries about excessive public debts are exaggerated. As a matter of macroeconomic theory, so long as the debt/income ratio is constant, an economy could live with any level of debt. Cecchetti et al. [22] take a lengthier and less friendly outlook of current developments, arguing that the aftermath of the financial crisis has brought the simmering fiscal troubles in industrial economies to the boiling point. The forecasts of public debt ratios lead Cecchetti et al. [22] to conclude that far-reaching actions are needed to limit the rapid growth of current and future liabilities of governments and reduce their unfavorable consequences for long-term growth and fiscal stability.

As mentioned earlier, two main problems states in the European Union with respect to economic growth and the public debt crisis are Greece and Spain [30]. The economic outlook is bleak for Spain. The weak points of Spain's economy are its high unemployment rate and its low productivity, which are interconnected. In 2007, Spain's unemployment rate was $8.3 \%$. By the end of November, the rate reached $19.4 \%$. That compares with an average rate of $10 \%$ among the 16 euro zone countries. The recession is forcing Spain to lessen its dependence on foreign investment from levels that approached a maximum of $10 \%$ of GDP prior to the crisis to only $3.6 \%$ during the third quarter of 2009. The government introduced the Law of the Sustainable Economy, which took effect in mid-2010. Its main goal is to build an economic model based on energy efficiency and new technologies. Educational reform (i.e. human capital formation) is also part of this new approach.

The politics of public debt vary by country. In some, due to unpleasant experiences, there is a culture of thriftiness. In others, however, extravagant official spending is commonplace. As an example of the latter, Michael Pento [31] reported that the Persian Gulf emirate of Dubai was seeking to defer debt payment on nearly $\$ 90$ billion in liabilities from its state-run companies. Like many other over-leveraged enterprises and some countries across the globe, the government of Dubai made a massive gamble on real estate that has turned out poorly. Even economic giants like Japan and the United States need to take heed, with the latter also suffering economically from the near failure of 
large real estate companies like Freddie Mac and Fannie Mae.

The examples produced over the last few years should send a stark warning to the U.S. as well as the European Union that they cannot continue to operate at current levels of monetary and fiscal extravagance. The ramifications of taking on too much debt are that unless the party in question can be bailed out, the de-leveraging process usually leads to default and insolvency. It makes no difference whether it is a business, like AIG, or a country. Either way, the entity in question must always be able to service its debt, either by generating revenue or by taxation. If the venture or state becomes too extended, it becomes dangerously dependent on continuous economic growth or on continually low interest rates. Taking these warnings to heart, Saudi Arabia's government, for instance, has used the budget surplus of recent years to reduce public debt from SR660bn (i.e. $\$ 176$ bn USD) in 2002, representing $82 \%$ of GDP, to SR237bn ( $\$ 63$ bn USD) in 2008, which represents $13.5 \%$ of gross domestic product. High oil prices led to record budget and external current account surpluses in 2008, despite the public expansionary fiscal policy and surge in imports. Part of the surplus has been used to repay domestic debt, which fell by $5 \%$ to $13.5 \%$ of GDP [32].

Reinhart and Rogoff [33] and others [34] in recent papers argued that higher debt may stunt economic growth. They reported that countries with a gross public debt exceeding $90 \%$ of their annual economic output tended to grow a lot more slowly. In particular for developed states above the $90 \%$ debt threshold the average annual growth rate was about $2 \%$ lower that for states with a public debt of less than $30 \%$ of their GDP. This is of particular importance to countries such as the U. S. where growth in government debt, for example, stood at $85 \%$ of GDP in 2009 and is expected to surpass $100 \%$ within 5 years. However, while they found that the threshold for public debt was similar in advanced and emerging economies, emerging markets faced a lower threshold for external debt, which is usually denominated in a foreign currency; When external debt reached $60 \%$ of GDP for emerging states, then annual growth declined by about $2 \%$.

In their book Public Debt and Economic Growth, Greiner and Fincke [35] observed that an increase in community liability must be accompanied by an increase in the primary surplus of the government to guarantee sustainability of public debt. They presented an endogenous growth model and assumed that the primary surplus rises as public debt increases so that sustainability of public debt is given. Endogenous growth theory holds that investment in human capital, innovation and knowledge are significant contributors to economic growth. Greiner and Fincke analyzed how different debt strategies affect stability and the long-run growth rate. It was demonstrated that the economy is always stable under a balanced public budget while when the government runs permanent deficits it is stable only if the primary surplus reacts sufficiently strongly to higher public debt. Furthermore, Greiner [36] also ran their endogenous growth model with human capital, where human capital formation is the result of public education. The government finances expenditures in the schooling sector by the tax revenue and by public deficit. A sensitivity analysis of the dynamics of the model was presented and it turns out that the parameter determining the reaction of the primary surplus to changes in public debt is decisive as concerns the stability of the model. This is a similar result to those reported by Cafisco [27], Cottarelli [28], and Furceri and Zdzienicka [29] in their public debt-GDP ratio studies. For more information on the importance of human capital formation see the last section in this paper which discusses whether political institutions cause economic growth, or whether, alternatively, growth and human capital accumulation lead to institutional improvement.

\section{ECONOMIC GOVERNANCE, PERFORMANCE AND EVOLUTION OF INSTITUTIONS}

Spence [4] noted that there is a lot of variety in governance. You have autocratic systems, dominant single parties, and full-fledged multiparty democracies. The governments that succeed have benefited from leadership which brings multi-stakeholders together. They choose roughly the correct economic model. In other words they made good policy decisions. They were also benevolent in the sense that they made good policy decisions to help improve the lives of all the people in their societies. Similar conclusions were drawn by Glaeser et al. [23] in the debates over whether political institutions cause economic growth, or whether, alternatively, growth and human capital accumulation lead to institutional improvement. Their results suggested that poor countries get out of poverty through good policies, often pursued by dictators, and subsequently improve their political institutions. Human capital was found to be a more basic source of growth than were institutions. This will be discussed in more detail in the next section.

Diverse economies have used various institutions to carry out functions at different times with varying amounts of success, as shown by the industrial policies and catch-up competition between different Asian states. The field of economic governance studies and compares these institutions and processes that support economic activity using empirical and case studies as well as theoretical models [37]. In contrast, corporate governance analyses the internal management of a corporation and the rules and procedures by which a corporation deals with its stakeholders. Corporate and economic governance are often connected since the problems faced by an internal organization (e. g. information and commitment costs) are often similar to property and contract transaction costs [38]. This section will deal primarily with economic governance.

The governments that fail tend to move wealth around rather than creating it through innovation and competition. In other words they make poor policy decisions with regards to having, for instance, open and economically competitive industries. If we look around the world, in economic terms, at failing performances there is usually a governing group that is pursuing its own interests somehow. A good example is in the comparison between Asia and Africa. Asian countries such as Japan, Taiwan, South Korea, Singapore and more recently China, were the poorest parts of the world right after World War II. They educated their people. The global economy opened, and they were successful. This turns out to be the durable basis of the creation of wealth; human capital, creativity, and innovation. Many African countries, 
such as Zimbabwe, on the other hand are still struggling. Rather than creating wealth through education, creativity and industrial competition, they simply moved wealth around from one segment of society to another.

Spence [4] argues that the governance institutions in the global economy are significantly behind market integration. In the present day there can be accidents, crises, and mismanagement or incomplete management; look at what happened to the Japanese economy after the combined tsunami and nuclear reactor disasters. The country's institutions are struggling to handle the new reality. Similarly, we can see the EU trying to resolve its fiscal problems which have resulted in part from poor economic governance. While there is progress, there is also a lot of uncertainty. Spence goes on to explain that the G20 is supposed to be the main place where priorities are set and where this is coordination. The EU institution was created to synchronize the major economies and to put them together. It remains to be seen whether or not this will be successful. We can speculate that the EU may need internal modifications in its governance structure, including tightening up on entry requirements.

Formal and informal institutions evolve under different conditions in order to best support economic growth in a country by protecting property rights, enforcing contracts and organizing collective action which provides the appropriate infrastructure of rules, regulations and information that are needed for workable arrangements among individual and corporate economic players [16, 37]. Landes [18], for instance, in his "Wealth and Poverty of Nations" has combined quantitative economic history with institutional analysis to produce a captivating historical overview of economic growth. What Landes does is to assess the mutual relationship between technology and society to analyze examples of states that succeeded as well as failed. DeLong [39] notes that several lessons from this book include: try to ensure that a state's government is a regime that enables innovation and production, rather than a government that maintains power by a redistribution of wealth from its enemies to its friends; recognize that the task of a less-productive economy is to imitate rather than innovate; and be familiar with that as things change we need to change with them.

The concept of economic governance covers many areas including institutions and organizational behavior, economic development and growth, industrial organization, law and economics, political economy and comparative economic systems. In order to get a better grasp of the concept he has organized it along different dimensions and categories covering the purpose as well as the nature of the institution (Table 2). The latter, for instance, were subdivided by Dixit [16] into four categories; formal state institutions that enact and enforce laws, including legislature, police, judiciary and regulatory agencies; private institutions, such as arbitration forums, that function under the state law; for-profit private institutions that provide information and enforcement, such as organized crime and security agencies; and group enforcement through social networks and norms.

As an example of the evolution of an early institutional structure, Greif et al. [15] reported on how groups of traders in medieval Europe took collective action to counter a ruler's incentives to violate the member's property rights. Another key instance from this period is the Magna Carta, also called Magna Carta Libertatum (the Great Charter of Freedoms), an English legal charter which was originally issued in 1215 [40]. Magna Carta required King John of England to proclaim certain rights pertaining to the country's citizens, respect legal procedures, and accept that his powers would be bound by the law. It supported what became the writ of habeas corpus, allowing appeal against unlawful imprisonment. Magna Carta was the most significant early influence on the governance process that led to the rule of constitutional law today, including the United States Constitution. It was the first document forced onto an autocratic ruler by a group of his subjects (i.e. the barons) in an attempt to limit his powers by law and protect their property rights.

The sequence of economic and political reforms matters, with Giavazzi and Tabellini [41] arguing that states that implement economic reforms first and then democratize do much better than those that follow the opposite route. A recent example of this is the transformation of the old Soviet Union into Russia and the evolution of modern China. The latter with its more flexible industrial policies and management system implementing economic reform first, has had a greater impact on the world economy.

Much debate remains about the exact measures of the excellence of an institution, and how these affect economic results. Furthermore, democracy and authoritarianism come in many different varieties. Barro [42] for example finds that there is an optimum level in the relationship between economic growth and degree of democratic freedom; more

Table 2. Various Dimensions of the Concept of Economic Governance [2, 16]

\begin{tabular}{|c|c|}
\hline Dimension & Categories \\
\hline Purpose of the institution & $\begin{array}{l}\text { - Protection of property rights against theft by other individuals and usurpation by the state itself or its agents } \\
\text { - Enforcement of voluntary contracts among individuals } \\
\text { - Provision of physical and regulatory infrastructure to facilitate economic activity and functioning of protection and } \\
\text { enforcement categories }\end{array}$ \\
\hline Nature of the institution & $\begin{array}{l}\text { - Formal state institutions that enact } \& \text { enforce laws, including legislature, police, judiciary, \& regulatory agencies } \\
\text { - } \quad \text { Private institutions, such as arbitration forums, that function under the state law } \\
\text { - For-profit private institutions that provide information and enforcement, such as organized crime and security } \\
\text { agencies } \\
\text { - Group enforcement through social networks \& norms }\end{array}$ \\
\hline
\end{tabular}


democracy raises growth when political freedoms are weak, but depresses growth when a moderate amount of freedom is already established. Persson [43] found that the exact type of democracy matters for developing policy and economic outcomes; parliamentary, proportional and permanent democracies appeared to encourage more growth promoting structural policies, whereas presidential and temporary democracies do not. The exact reason for this is not well understood even after reviewing the literature on lawmaking organizations [44].

In a report for the World Bank, Kaufman et al. [45] constructed six measures of institutional quality (Table $\mathbf{3}$ ). Three of these, rule of law, control of corruption, and political instability and violence, deal with protection of property rights and enforcement of contracts while the first one, voice and accountability relates to governance since good communication can reduce problems between citizens and agencies of the state. Governance is also affected by government effectiveness and regulatory burdens. It can be argued, however, that the method of construction of these six measures of institutional quality relies on subjective perception.

The protection of property rights supplied by the state is often supplemented by private security agencies; the latter works cooperatively with the police. In addition, information gathering constitutes a major source of advantage for private agencies/ systems over formal law [16]. Enforcement of a contract in a court of law, for example, requires proof of misconduct by one of the parties. Information gathering can be done more effectively by private agencies. The most notable item about commercial contract disputes is that private alternatives, such as arbitration by industrial experts, are almost always tried first. Only as a last resort will one of the parties file a suit in a formal court of law [9]. The advantages of expert arbitration are often recognized by formal legal systems with the courts standing ready to enforce the decisions of expert industry arbitrators.

Formal governance at the international level works through institutions such as the World Trade Organization. The procedures of their sovereign country members are subject to self-enforcement and are thus similar to social networks [46]. Arbitration of international contract disputes works in a similar way [47]. While such arbitrators lack direct power to enforce their decisions, they are normally backed by treaties that ensure enforcement by national courts.

Organized crime also plays a role in governance $[48,49]$. If a state, for example, is unwilling to protect certain kinds of property or enforce certain kinds of contracts, such as illegal activities, then private institutions, such as organized crime, can emerge to perform these functions for a profit. Gambetta [48] argues that the Mafia emerged in $19^{\text {th }}$ century Sicily in order to fill a vacuum left by a lack of state protection. Landowners started hiring guards from former feudal lords, as well as bandits, to protect their property. Eventually the Mafia's role expanded to provide contract enforcement in illegal markets. In a similar fashion the Japanese Yakusa evolved just after the end of the Second World War, and the Russian mafia after the fall of the Soviet Union; in both cases to fill a vacuum left by a temporary weak state $[50$, 51].

The information function of organized crime, such as the Mafia, is comparable to that of credit ranking agencies and Better Business Bureaus [52]; keeping track of previous contract violations, informing a customer of the history of a potential business partner, and providing punishment if a customer's trading partner violates their contract. In the case of a Mafia enforcer, anyone who cheats a customer of the Mafioso is subject to the possibility of physical violence. With a Better Business Bureau, if a company misbehaves, after having joined the organization, then it is subject to a poor rating or blacklisting. As economic activity increases, formal institutions usually become better than informal ones, but the latter provide a useful function under the shadow of formal ones, even in the most advanced economies.

\section{ECONOMIC GROWTH, INDUSTRIAL RACING AND CATCH-UP}

A foremost mechanism to sustain economic expansion among nations lies in the industrial catch-up processes among leaders and stragglers. This is born out of rivalry for enhanced performance, and is similar to competitions between teams in sporting events. How the interactive patterns of growth and development emerge in a historical context is the foremost subject of a recent book by Gottinger and Goosen [2] on Strategies of Economic Growth and Catch-up: Industrial Policies and Management. It establishes a link between progress and expansion economies and assesses the mechanisms of growth facilitating factors that support technology-based growth processes over time with technology as a leading source and institutional inefficiencies as binding constraints. Furthermore, understanding how industries, supported by effective industrial policies, make optimal investments in the face of dynamic competition helps to reveal the nature of inter-country competition and industrial advantage. Another source of racing behavior can be linked to 'animal spirits'

Table 3. Measures of Institutional Quality (Adapted from Kaufman et al. [45] and Dixit [16])

\begin{tabular}{|c|c|}
\hline Type of Quality & What is Measured? \\
\hline Voice \& accountability & - Political, human and civil rights \\
\hline Government effectiveness & - Competence of bureaucracy \& quality of public service delivery \\
\hline Regulatory burden & - Incidence of market unfriendly policies \\
\hline Control of corruption & - Exercise of public power for private gain, including petty and grand corruption and state capture \\
\hline
\end{tabular}


and innovation through entrepreneurship. In competitive analysis involving $R \& D$ decisions the focus is on breakthrough innovations which could create entirely new markets; for example, as occurs in studies featuring patent racing between competing firms.

In a related book The Next Convergence, The Future of Economic Growth in a Multispeed World, Spence [4] also debated the dynamics of high-speed growth (i.e. catch-up growth). A key element in it is that the knowledge of what we have learned over the past several hundred years in the developed countries can be used by emerging nations, so they do not have to learn it all over again. That saves time and increases their potential output. The second vital component is the need for emerging nations in the catch-up growth stage to invest and save. Spence explains, for example, that China in 1978, when it started growing rapidly, was investing and saving at 35 percent, or a third of the country's GDP. The third mechanism that is really critical is that emerging states have to sell what they produce in a global market. In a poor country, such as China was say 20 years ago, the domestic economy was used to primarily generating housing and food, and consuming some energy. The economy of an emerging nation cannot be scaled-up selling only to such a limited domestic market. So these countries invest at very high rates, intensify the scope of the developing part of the economy, attract workers into it, and then sell into a worldwide market. China is the latest example if a state that has successfully used this process. So the key for the EU and the USA is the need to get a larger share of the world market over the coming years when selling their products in an increasingly competitive environment.

The rapid development of a number of Asian economies, in contrast to the UK and the US, is shown in Table 4, where variations in GDP per capita are compared. All five countries went through different stages of industrialization within a period of 300 years. Mokyr [53] in The Lever of Riches argues that technological creativity and subsequent growth was a contributing factor in the rise of the West. According to Mokyr two main factors were involved in the unbelievable surge in European technological creativity; money-oriented common sense that encouraged Europeans' attempts to control the environment, and the divided character of European political structure that spurred competition, (i.e. industrial racing) since many countries feared to fall behind their neighbors.

As described earlier, industrial competition among nations or regional economic entities has been an essential driving force for economic growth [2]. Rivalry pushes a state's standing, prestige, power and economic performance thus allowing a country or a region to get ahead of their competition. Institutions can support this competitive process by encouraging entrepreneurship, fostering education and training, and by making it easier for companies to set up new businesses. We can argue that economic growth essentially embodies a science and technology race between industrialized nations. This economic or industrial contest creates value added products through competition as reflected in an increased GDP. Prime examples of this catch-up process are the countries in the Arabian Gulf (e.g. Saudi Arabia, Kuwait, UAE, Oman, Qatar and Bahrain). Increased revenues from oil resources over the past few decades are being used, for instance, to set up new educational institutions. In Saudi Arabia the number of universities has more than doubled, increased from 10 to 24 over a period of 5 years (NAJD Online Academy [56]). In addition the government has implemented a Science and Technology Strategic Plan called Vision 2020 to help diversify the economy [57]. To assist in this development, entrepreneurship is being encouraged through workshops, and programs such as Badir [58]. Badir is an initiative of Saudi Arabia's National Research Institute - King Abdulaziz City for Science and Technology (KACST). The initiative aims to assist people in the commercialization of technology research and opportunities through supporting the growth of emerging technology-based businesses in the Kingdom. It remains to be seen if the country can improve its efficiency sufficiently to make a success of this program.

There is also an increase in the participation of women in the Arabian Gulf region's governmental institutions even up to the cabinet level. In Oman, for example, the head of state and government is the hereditary Sultan who appoints a cabinet called the Diwans to assist him. In the early 1990s, the Sultan instituted an elected advisory council, the Majlis ash-Shura, though few Omanis were eligible to vote. Universal suffrage for those over 21 was instituted in 2003 and over 190,000 people ( $74 \%$ of those registered) voted to elect the 84 seats [59]. Two women were elected to seats. The country in 2010 also had three women ministers (i.e. Minister of Higher Education, Minister of Social Development and Minister of Tourism). While there are no legal political parties nor, at present, any active opposition movement, as more and more young Omanis become educated, it seems likely that the traditional, tribal-based political system will have to be adjusted. Many of the Arabian Gulf countries are going through a similar catch-up process in human capacity building and institutional structures development. Glaeser et al. [23] argues that much evidence points to the dominance of human capital for both

Table 4. Historical Change in Per Capita GDP, in Terms of 1990 International Geary-Khamis Dollars, of Five Countries (Adapted from Maddison [54] and [55], and Gottinger and Goosen [2])

\begin{tabular}{|l|c|c|c|c|c|c|c|c|c|c|}
\hline & $\mathbf{1 7 0 0}$ & $\mathbf{1 8 2 0}$ & $\mathbf{1 8 7 0}$ & $\mathbf{1 9 0 0}$ & $\mathbf{1 9 2 0}$ & $\mathbf{1 9 4 0}$ & $\mathbf{1 9 6 0}$ & $\mathbf{1 9 8 0}$ & $\mathbf{1 9 9 5}$ & $\mathbf{2 0 0 3}$ \\
\hline \hline UK & 1250 & 1706 & 3190 & 4492 & 4548 & 6856 & 8857 & 12931 & 17495 & 21310 \\
USA & & 1257 & 2445 & 4091 & 5552 & 7010 & 11328 & 18577 & 24484 & 29037 \\
Japan & & 669 & 737 & 1180 & 1696 & 2874 & 3986 & 13428 & 19849 & 21218 \\
S. Korea & & 600 & 604 & - & 1009 & 1442 & 1105 & 4114 & 11818 & 14673 \\
China & & & 530 & 545 & - & - & 673 & 1067 & 2653 & 4803 \\
\hline
\end{tabular}


industrial growth and democratization. Their results were consistent with a perspective on institutions outlined by Djankov et al. [60]; the greater the human and social capital of a community, the more attractive are its institutional opportunities.

The collective nature of science and technology development is at the root of industrialization and economic progress. Institutions can assist in this technology race by helping to identify the most promising skill options, and by promoting entrepreneurship [61]. This can be done, for instance, through government sponsored strategic workshops for the private and public sectors. Abramovitz [62] explained the central idea of the catch-up hypothesis as trailing countries adopting a backlog of unexploited technology. While a leader is restricted in increasing its productivity by the advance of new technology, trailing countries, such as China, India and the Arabian Gulf states, have the potential to make a larger leap as they are provided with the privilege of exploiting the backlog in addition to newly developed technology. Formal institutions can assist in exploiting this potential by instigating technological entrepreneurship programs through government incentives, as well as by fostering education. Years of education can be used as a replacement for technical competence. This concept is most closely associated with the work of Lipset [63], Przeworski $[64,65]$, and Barro [42] who believed that educated people are more likely to resolve their differences through negotiation and thus provide greater stability which in turn is the key to economic growth. This is similar to the concept that knowledge is essential to the dynamics of high-speed growth (i.e. catch-up growth) as put forth by Spence [4].

Gottinger [17] and Gottinger and Goosen [2] describe the development of a model to analyze the patterns of catching up, falling behind and getting ahead in technological racing (i.e. industrial competition) among nations or regional economic entities. The impact of social institutions arises by allowing the potential technology gap to be modified by them. It allows for more complex growth dynamics. The model achieved the goal of merging the neoclassical system with slow technology diffusion and institutional variations. Model predictions and empirical observations indicated that new technology adoption rates vary between countries. This variance could be mostly due to the social capabilities of those countries that demonstrate various competence levels of adoption promoted by bureaucratic efficiency, including a low level of corruption, and democratic rights [66]. A good example is Latin America which carries relatively high adoption rates but overall the region has failed to take advantage of its potential because of poor political and social institutions.

In terms of catch-up times, Gottinger [17] and Gottinger and Goosen [2] demonstrate that unless Europe, East Asia and even the Arabian Gulf, reduce their inefficiency levels, they must rely on higher accumulation rates to continue to catch-up with countries such as the United States. Institutional frameworks are important in achieving this improved efficiency. The bureaucratic efficiency index and the index of political and civil rights, for instance, are the main explanations for a nation's different level of productivity. Any policy that allows follower nations to better adopt foreign technology should increase their growth rate. Since the difference in technology adoption appears to be related to a nation's institutional efficiency, observations suggest that governments are well-advised to pursue policies that increase market efficiency.

In summary, a key mechanism to sustain economic expansion among nations lies in the industrial catch-up processes among leaders and laggards that are born out of rivalry for enhanced performance. Key elements in the catchup process are the use of knowledge by emerging states, learned over the past several hundred years by developed states, to help set up or mimic industrial processes. That saves time and increases output. The second crucial component is the need for emerging nations in the catch-up growth stage to invest and save. The third mechanism that is really vital is that emerging states have to sell what they produce on a global scale. Institutions can complement, support and advance the technological race process by enhancing the opportunities for technological entrepreneurship, by fostering education and training, particularly of women in developing economies and by business deregulation in order to improve efficiency.

\section{ECONOMIC GROWTH FORECASTS WITH GLOBAL ECONOMETRIC MODELS}

Simulations with econometric or mathematical models can depict the interdependencies between the environment, and economic and social development [67]. An econometric model is one of the tools economists use to forecast or predict future growths in the economy. Past relationships are measured, for example, among such variables as consumer spending, household income, tax rates, interest rates, and employment, and then forecasts are made on how changes in some variables will affect the future course of others. The application of a global model GINFORS by Meyers et al. [67] in 2004 forecasted a worldwide economic recovery till 2010 (Fig. 1). Their calculations indicated that China and the South East Asian countries would be the most dynamic economies, the United States would be in a middle position, followed by the United Kingdom, and the EU area would have the weakest growth. We can argue that while the general economic trend that we observe today for the EU and Asia was correctly predicted by the GINSFORS model, the country specific problems with for example, Greece and Spain were not.

In a related study, Lukáš and Jan [68] reported on the application of an econometric panel data model for regional competitiveness evaluation in 15 selected EU countries (Fig. 2). The three most competitive regions belonged to Groningen in Netherlands, Stockholm in Sweden and Southern and Eastern Ireland. All these regions are highly developed according to the value of their GDP per inhabitant which was higher than the EU average. The three least competitive regions belonged to Dytiki Macedonia, Ipeiros in Greece and Flevoland in Netherlands. These three regions were less developed according to the value of their GDP per inhabitant which was lower than the EU average. It is important to note here that the model correctly predicted that Greece is an economically weak region.

Economic output may vary between regions for a multitude of diverse causes (Fig. 2). Lukáš and Jan [68] noted that it important to be able to predict how such 


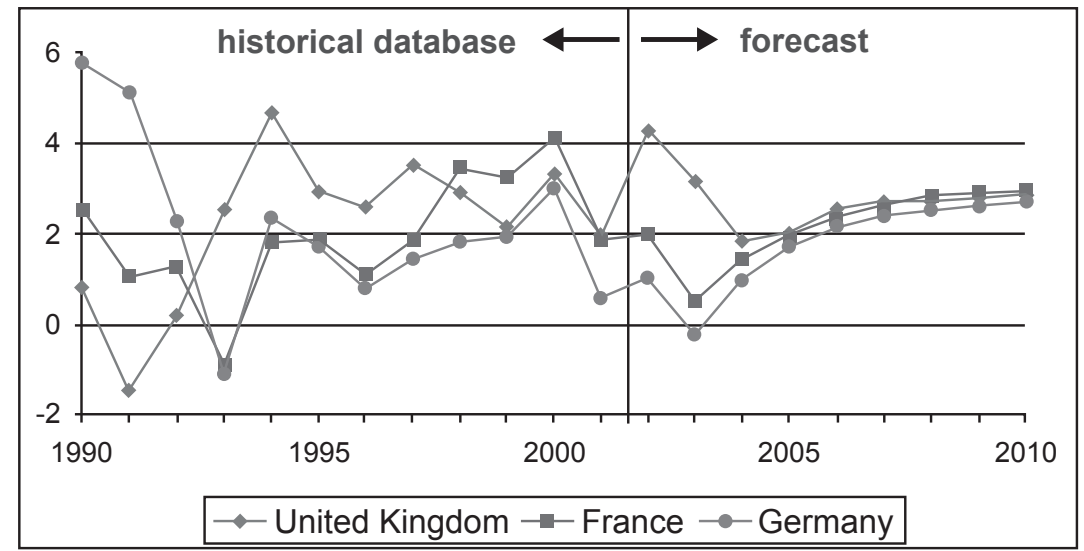

Fig. (1). Growth rates of real GDP for selected European countries [67]. Economic growth of three EU countries was forecast with the Global Econometric Model GINFORS.

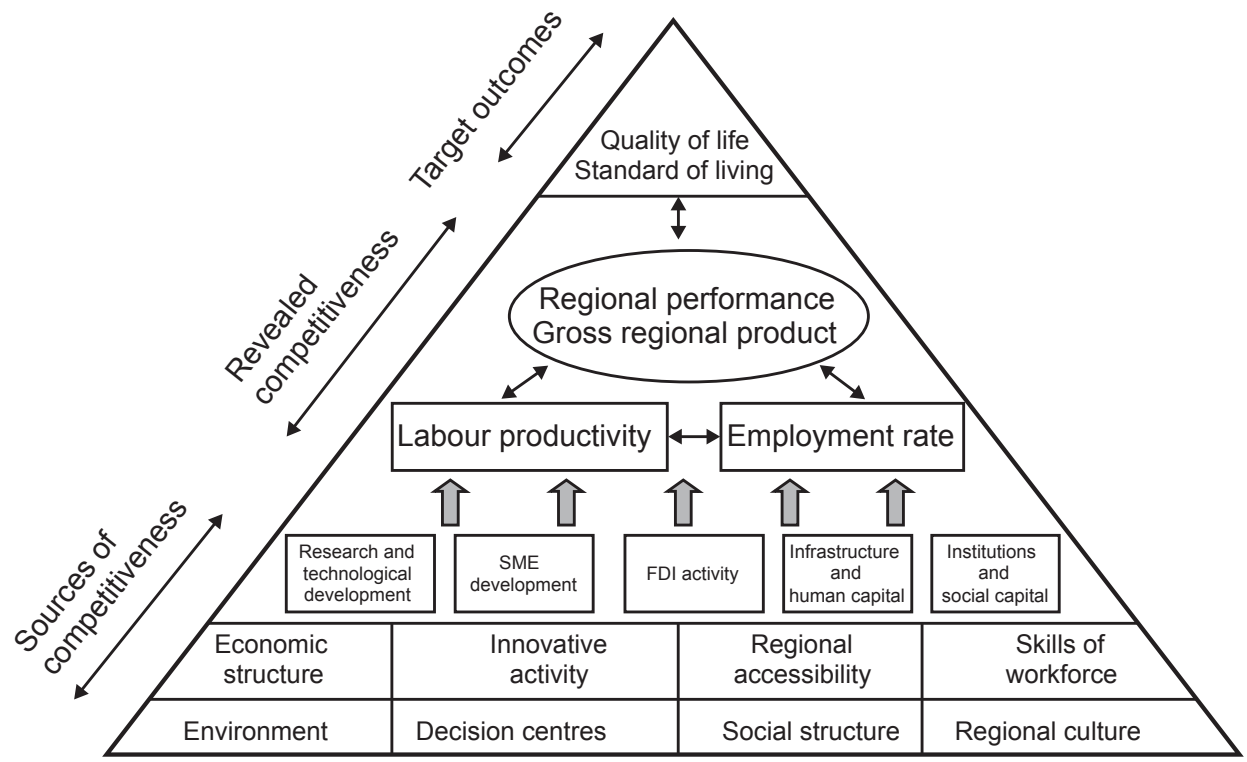

Fig. (2). Pyramid model of regional competitiveness [68].

differences evolve over time. In the standard neoclassical model the growth of productivity (i.e. output per worker) depends on the growth of capital per worker and the rate of technical progress. Regional differences in productivity growth were explained by regional differences in the rate of technical progress and by regional differences in the growth of the capital labour ratio. Regional output variances were predicted to narrow over time, as initially low productivity areas catch up with originally high productivity ones.

Waczriarg [69] in his review of Easterly's “The Elusive Quest for Growth" [70] noted that qualitative efforts to explain the bases of growth, and therefore to determine the policies that could solve the problem of underdevelopment, have often been viewed with cynicism by those economists who favor quantitative empirical work (i.e. econometric models). The latter are closely associated with optimization models, recognizable institutional arrangements or determinants, and large samples of data. He goes on to argue that William Easterly provides us with simple mathematical correlations or regression models chosen from the crosscountry growth literature originating from the World Bank.
One key feature of Easterly's book that has attracted the greatest attention was its disapproval of existing aid policies. Easterly explains the sequence of adjustment loans directed by the World Bank and IMF at countries that waste these resources on current consumption rather than on investment. This waste leads to stagnant growth, debt crises, debt relief, and further adjustment loans.

Easterly [70] carefully reviews recent empirical studies on the determinants of economic growth, focusing on correlations between economic performance and its determinants based on the most-often cited papers in this literature. For example, the partial correlation between indicators of corruption and growth is negative, in a wide variety of specifications. Waczriarg [69] explains that this, clearly, does not imply that corruption negatively impacts growth. But the sign of the partial correlation makes it more difficult to argue that corruption is in fact good for growth, or, equivalently, that an increase in corruption would lead to an increase in growth. 
Today economists use Solow's sources-of-growth econometric accounting models to estimate the separate effects on economic growth of technological change, capital, and labor. These neoclassical growth models, also known as the Solow-Swan growth models, attempt to explain long run economic growth by looking at productivity, capital accumulation, population growth, and technological progress [71-73]. Solow's model has been successfully fitted to available data on US economic growth. In 1987, Solow received the Nobel Prize in Economics for his work. Solow was also the first economist to develop a growth model which distinguished between vintages or the age of capital. New capital is more valuable than old capital because, since capital is produced based on known technology, and technology improves with time, new capital will be more productive than old capital [74].

As Easterly reminds us, the only determinant of longterm per-capita income growth in the Solow model is laboraugmenting technological progress. There is an ongoing debate on the importance of human capital accumulation for growth since early studies found strong support for the hypothesis that at least some measures of human-capital accumulation have statistically significant predictive power [6]. The importance of human capital accumulation for growth is debated in more detail in the next section. The preponderance of the evidence is that the neoclassical determinants of growth do enter significantly in growth regressions. These are the theories that stress incentives to innovate or accumulate capital as necessary conditions for innovation and accumulation to occur. This was covered in some detail in the previous section on Economic Growth, Industrial Racing and Catch-up.

Econometric models have shown that accumulation variables and population growth play some part in accounting for the cross-country variation in growth [69-70]. Institutions, geography, economic and political structures, policies and governance relate to the incentives to innovate and accumulate, and go some way toward explaining the rest of the variation. This arrangement of limited connections provides some indication of the sources of growth, but their interpretation as causal effects is usually awkward. In particular, there is a need to clarify and estimate the theoretical relationships that link structures and policies to accumulation and innovation.

In summary, econometric models are useful as additional tools in forecasting economic growth in regions such as EU. However, they are not fool proof tools and are at best, in our opinion, good for predicting general trends. Such models must be used in conjunction with qualitative information and the experience and knowledge of professional economists in forecasting economic growth. As Easterly [70] notes, the quest for the perfect econometric model that correctly describes economic growth remains elusive.

\section{THE DEBATE OVER WHETHER OR NOT POLITICAL INSTITUTIONS CAUSE ECONOMIC GROWTH}

Glaeser et al. [23] revisited the discussion over whether political institutions cause economic growth, or whether, alternatively, growth and human capital accumulation lead to institutional improvement. They found that most indicators of institutional quality used to establish the proposition that institutions cause growth, as outlined for example in North's and Olson's theories [24, 25] were constructed to be conceptually unsuitable for that purpose. Results suggested that human capital is a more basic source of growth than are the institutions; poor countries get out of poverty through good policies, often pursued by dictators, and subsequently improve their political institutions. Furthermore, Spence [4] maintained that there is a need to invest in people, knowledge, technology, and infrastructure; this encourages investment and creates employment.

Economic research has identified two broad approaches to confronting the challenges in establishing a self-governing state. The first approach, which is supported by North [24] and Olson [25], emphasizes the need to start with democracy and other checks on government as the mechanisms for securing property rights. With such political institutions in place, investment in human and physical capital, and therefore economic growth, are expected to follow. The second approach supported by Glaeser et al. [23] emphasizes the need for human and physical capital accumulation to start the process. It holds that even pro-market dictators can secure property rights as a matter of policy choice, not of political constraints. From the vantage point of poor countries, it sees democracy as the consequence of increased education and wealth, not as their cause.

The importance of constraining government has been stressed by many economists starting with Montesquieu [75] and Smith [76]), and up to recent times by Hayek [7], as well by the new institutional economists [75, 77]. Montesquieu [75], for example, spent nearly twenty years researching and writing L'esprit des lois (The Spirit of the Laws), covering a wide range of topics in politics, the law, sociology, and anthropology and providing several thousand citations. In this political treatise Montesquieu supports constitutionalism and the separation of powers, the abolition of slavery, the preservation of civil liberties and the rule of law, and the idea that political and legal institutions should reflect the social and geographical character of each particular region.

Friedrich August von Hayek was an Austrian-born economist and philosopher known for his defense of classical liberalism and free-market capitalism against socialist and collectivist thought. He is considered by some to be one of the most important economists and political philosophers of the twentieth century [78]. Hayek was one of the leading academic critics of collectivism in the 20th century. Hayek argued that all forms of collectivism (even those theoretically based on voluntary cooperation) could only be maintained by a central authority of some kind. In his popular book, The Road to Serfdom, written in 1944, and in subsequent works, Hayek argued that socialism requires central economic planning and that such planning in turn leads towards totalitarianism [7]. Recent work, including Hall and Jones [79], DeLong and Shleifer [80], Acemoglu et al. [81, 82], Easterly and Levine [83], and Rodrik et al. [84], has reached close to an intellectual consensus that the political institutions of limited government cause economic growth. The reverse idea, namely that growth in income and human capital causes institutional improvement, is most closely associated with the work of Lipset [63] who believed that educated people are more likely to resolve their 
differences through negotiation and voting than through violent disputes. Education is needed for courts to operate and to empower citizens to engage with government institutions.

Countries differ in their stocks of human and social capital, which can be acquired through policies pursued even by dictators. Institutional outcomes depend to a large extent on these endowments [60]. This is supported by the experiences of South Korea, Taiwan, and China, which grew rapidly under one-party dictatorships, the first two eventually turning to democracy. Empirically, Lipset's hypothesis that growth leads to better political institutions has received considerable support in the work of Przeworski $[64,65]$ and his associates [42, 85]. The two views of economic and political development share some important similarities. They both emphasize the need for secure property rights to support investment in human and physical capital, and they both see such security as a public policy choice. However, the institutional view sees the pro-investment policies as a consequence of political constraints on government, whereas the development view sees these policies in poor countries largely as choices of their leaders.

Glaeser et al.'s [23] view was shaped by the experiences of North and South Korea. Prior to the Korean War, the two countries were one state with similar histories (note that they were occupied by Japan from 1910 to 1945). They were also both exceptionally poor in 1950. Between the end of the Korean War and 1980, both countries were autocracies (i.e. dictatorships). South Korean dictators chose capitalism and secure property rights, and the country grew rapidly, reaching a per capita income level of US \$1589 in 1980. The North Korean dictators, in contrast, chose socialism, and the country only reached the level of income of US \$768 in 1980. South Korea obviously had better institutions as measured by constraints on the executive, these institutions were the outcome of economic growth after 1950 rather than its cause. Glaeser et al. [23] goes on to argue that it would be wrong to attribute South Korea's growth to these institutions rather than the choices made by its dictators.

Assessing the underlying connection between institutions and economic growth has proved particularly complex. The research approaches as outlined by North [24], Olson [25], Hall and Jones [79], DeLong and Shleifer [80], and Acemoglu et al. [81, 82] do not clearly show that political institutions rather than human capital have a causal effect on economic growth. Certainly, Glaeser et al. [23] goes on to argue that much evidence points to the dominance of human capital for both growth and democratization. Their results were consistent with a perspective on institutions outlined by Djankov et al. [60]; the greater the human and social capital of a community, the more attractive are its institutional opportunities. Institutions are highly persistent because history, including colonial history, shapes social choices. Furthermore institutional outcomes also get better as a society grows richer, because institutional opportunities improve. Importantly, in that framework, institutions have only a second order effect on economic performance. The first order effect comes from human and social capital, which shape both institutional and productive capacities of a society.
The results of the paper by Glaeser et al. [23] do not show that institutions do not matter. That proposition is contradicted by a great deal of available empirical evidence that has been provided by North [24], Olson [25], Hall and Jones [79], DeLong and Shleifer [80], and Acemoglu et al. $[81,82]$. Rather, Glaeser et al.'s [23] results suggest that the current measurement strategies have conceptual flaws, and that researchers would do better focusing on actual laws, rules, and compliance procedures that could be manipulated by a policy maker to assess what works.

A key factor for poor countries is the policy choices made by autocrats. Democratization and constraints on government do not need to come first. The economic success of East Asia in the post war era and of China most recently, for example, has been a consequence of good economic policy decisions by autocrats, not of institutions constraining them. The Chinese example illustrates this point convincingly: Deng was one of the best dictators for economic growth while Mao was one of the worst. While Mulligan et al. [86] present compelling evidence that democracies are significantly more compassionate than dictatorships in such policy areas as freedom of the press, torture, death penalty, and regulation of religion, Glaeser et al.'s [23] evidence suggests that the Lipset [63], Przeworski $[64,65]$, and Barro [42] view of the world is more accurate: countries that emerge from poverty accumulate human and physical capital under dictatorships, and then, once they become richer, are increasingly likely to improve their institutions.

\section{CONCLUDING REMARKS}

Institutional aspects of economic growth have been critically reviewed with emphasis on the fiscal crisis facing the European Union (EU). The EU monetary calamity poses a hazard to the economic and financial stability of the world. It can be argued that numerous governance institutions in the global economy are out of phase with the market conditions. In the present day there can be accidents, crises, and mismanagement or incomplete management. The Japanese economic governance institutions, for example, are struggling to handle the new reality after the combined tsunami and nuclear reactor disasters. Similarly, we can see the EU trying to resolve its fiscal problems which have resulted in part from poor economic governance. While there is progress, there is also a lot of uncertainty. It remains to be seen whether or not the resolution of this problem will be successful. The EU may need internal modifications in its governance structure, including tightening up on entry requirements.

Concern over the sustainability of some EU countries' public debt has continued to increase over the past few years. While things will improve there is no quick fix. Greece and Portugal had unsustainable fiscal policies well before the 2008-2009 financial crisis; for Spain and Italy there is uncertainty about debt sustainability primarily due to worries about their future economic development. The key to solving these issues is to build up budget surpluses. However, this will take time. The projections of public debt ratios lead many experts to conclude that the path pursued by fiscal authorities in a number of industrial states is unsustainable. Far-reaching actions are required to limit the fast growth of 
current and future liabilities of governments and reduce their unfavorable consequences for long-term growth and fiscal stability. Furthermore, econometric models are useful as additional tools in forecasting economic growth in regions such as EU. However, the quest for the perfect econometric model that correctly describes economic growth remains elusive. Such models must be used in conjunction with qualitative information and the experience and knowledge of professional economists in forecasting economic growth.

A foremost mechanism to sustain economic expansion among nations lies in the industrial catch-up processes among leaders and stragglers. This is born out of rivalry for enhanced performance, and is similar to competitions between teams in sporting events. Important elements in the catch-up process are the use of knowledge by emerging states, learned over the past several hundred years by developed states, to help set up or mimic industrial processes. That saves time and increases output. The second crucial component is the need for emerging nations in the catch-up growth stage to invest and save. The third mechanism that is really vital is that states have to sell what they produce on a global scale.

If we were to try and weigh institutional factors in as far as they tend to affect economic growth. Positive factors on growth include consensual political systems that are flexible, a competitive environment with fiscal incentives that allows for continuous improvement in efficiency, industrial competition that allows for economic choices, and a well developed educational system to help provide competent human capital for formal institutions such as courts. Negative institutional factors affecting economic growth are corruption due to fiscal and political decentralization resulting in stagnation due to reduced economic choices, autocrats or dictators that make poor policy choices, and high public debt in relation to a state's annual economic output. In closing, the relationship between institutions and economic performance is complicated. However, there is now convincing evidence that countries that have an open, technologically competitive and creative environment tend to perform better economically.

\section{CONFLICT OF INTEREST}

The author confirms that this article has no conflict of interest.

\section{ACKNOWLEDGEMENTS}

Special thanks go out to Dr. Hans W. Gottinger the Executive Director of STRATEC in Germany for his help in reviewing this article and for his useful comments and suggestions.

\section{REFERENCES}

[1] Goosen MFA. In: Gottinger H, Goosen MFA, Eds. Strategies of Economic Growth and Catch-up: Industrial Policies and Management. New York: Nova Science 2012; pp. 133-62.

[2] Gottinger H, Goosen MFA, Eds. Strategies of economic growth and catch-up: industrial policies and management. New York: Nova Science 2012.

[3] Daianu D. Euro zone crisis and EU governance: tackling a flawed design and inadequate policy arrangements (January 1, 2012). CASE Network Studies and Analyses No. 433. Available from: http://ssrn.com/abstract=1991162 or http://dx.doi.org/10.2139/ssr n.1991162 [Cited: 2011 February 23]
[4] Spence M. The next convergence, the future of economic growth in a multispeed world. New York: Farrar, Strauss and Giroux 2011.

[5] Wapshot N. Keynes Hayek: the clash that defined modern economics. New York: WW Norton \& Company 2011.

[6] Barro RJ. Determinants of economic growth: a cross-country empirical study. Cambridge, MA: MIT Press 1998.

[7] HayekFA von. The constitution of liberty. London: Routledge 1960

[8] Hayek FA von.The road to serfdom, 50th anniversary edition. Chicago: Univ. Chicago Press 1994.

[9] Williamson O. The mechanism of governance. New York: Oxford University Press 1995.

[10] Barro RJ.The stimulus evidence one year on. Wall St J, Opinion, 23 February 2010.

[11] Becker GS. The great recession and government failure. Wall St J, Opinion, 2 September 2011.

[12] Abrams BA, Lewis KA. Cultural and institutional determinants of economic growth: a cross-section analysis. Public Choice 1995; 83: 273-89.

[13] Loomis CM. The politics of uncertainty: lobbyists and propaganda in early twentieth-century America. J Policy Hist 2009; 21: 187213.

[14] Schlueter A. Institutions as economic growth determinants: a comparative study of New Zealand and Argentina. Masters Diss.; AUT 2007. Available from: http://hdl.handle.net/10292/697.

[15] Greif A. Institutions and the path to the modern economy: lessons from medieval trade. Cambridge: Cambridge University Press 2006.

[16] Dixit A. Economic governance: Conference on Endogenous Market Structures and Industrial Policy, 5 June; Aula Magna, Milano 2008

[17] Gottinger H. Strategic economics of network industries. New York: Nova Science 2009.

[18] Landes DS. The wealth and poverty of nations: why some are so rich and some are so poor? New York: WW. Norton \& Co 1998.

[19] North DC. Institutions and the process of economic change. ManagInt 2005; 9: 1-83.

[20] North DC. Understanding the process of economic change. Princeton: Princeton University Press 2005.

[21] Baumgartner FR, Leech BL. Basic interests: the importance of groups in politics and in political science. Princeton, NJ: Princeton University Press 1998; pp. 64-82.

[22] Cecchetti SG, Mohanty MS, Zampolli F. The future of public debt: prospects and implications. Bank for International Settlements March 2010; pp. 1-22. Available from: http://www.bis.org/ [Cited: 17 January 2013].

[23] Glaeser EL, La Porta R, Lopez-de-Silanes F, Shleifer A. Do institutions cause growth?J Econ Growth2004; 9: 271-303.

[24] North DC. Economic performance through time. Am Econ Rev1994; 84(3): 359-68.

[25] Olson M. Power and prosperity: outgrowing communist and capitalist dictatorships. New York: Basic Books 2000.

[26] Jolis A. A supply-sider in East Africa. Wall St J 2010; 24 April.

[27] Cafisco G. Debt development and fiscal adjustment in the EU. Interecon 2012; 47: 61-7.

[28] Cottarelli C. Sovereign debt crisis: why in Europe and not elsewhere? Interecon 2012; 47: 74-5.

[29] Furceri D, Zdzienicka A. The consequences of banking crises for public debt (March 25, 2010). Bank of Italy Occasional Paper 2010.Available from: http://ssrn.com/abstract=1985237 or http://dx.doi.org/10.2139/ssrn.1985237.

[30] Wharton University. Spain in 2010: will unemployment prolong the economic crisis? 2010. Available from: http://www.wharton.uni versia.net/index.cfm?fa $=$ printArticle $\& I D=1830 \&$ language $=$ english [Cited: 11 June 2010].

[31] Pento M. Dubai may be least of world's debt problems. Forbes.com 2009. Available from: http://www.forbes.com/2009/12/01/michaelpento-commentary-personal-finance-record-debt.html [Cited: 11 June 2010].

[32] AMEinfo.com. 2009. Saudi Arabia: Public debt reduced to SR237bn. Available from: http://www.amei nfo.com/212221.html [Cited: 29 July 2010].

[33] ReinhartCM,Rogoff KS. Growth in a time of debt. Am Econ Rev 2010; 100(2): 573-8.

[34] Reinhart CM, Rogoff KS. Higher debt may stunt economic growth. Wall St J 2010; 4 January. 
[35] Greiner A, Fincke B. Public debt and economic growth: dynamic modeling and econometrics in economics and finance. Berlin: Springer 2009.

[36] Greiner A. Human capital formation, public debt and economic growth. J Macroecon 2008; 30(1): 415-27.

[37] Williamson O. The economics of governance. Am Econ Rev 2005; 95: 1-18.

[38] Coase R. The nature of the firm. Economica 1937; 4(16): 386-406.

[39] Delong JB. Review of David Landes the wealth and poverty of nations: why some are so rich and some are so poor? New York: WW. Norton \& Co 1998.

[40] Holt JC. Magna carta. Cambridge; Cambridge University Press 1992.

[41] Giavazzi F, Tabellini G. Economic and political liberalization. J Monetary Econ 2005; 57 : 1297-330.

[42] Barro RJ. Determinants of democracy. J Polit Econ 1999; 107: 15883.

[43] Persson T. Forms of democracy, policy, and economic development. Working Paper No. 11171. Cambridge, MA: NBER 2005.

[44] Keefer P. What does political economy tell us about economic development - and vice versa? Annu Rev Polit Sci 2004;7: 247-72.

[45] Kaufman D, Kraay A, Mastruzzi M. Governance matters IV: updated governance indicators 1996-2004. Washington DC: World Bank research paper. 2005. Available from: http://www.worldbank. org/wbi/governance/pubs/govmatters4.html [Cited: 8 February 2010].

[46] Bagwell K, Staiger R. The economics of the world trading system. Cambridge, MA: MIT Press 2003.

[47] Mattli W. Private justice in a global economy: from litigation to arbitration. Int Org 2001; 55: 919-47.

[48] Gambetta D. The Sicilian mafia: the business of private protection. Cambridge, MA: Harvard University Press 1993.

[49] Bandiera O. Land reform, the market for protection and the origins of the Sicilian mafia: theory and evidence. J Law Econ Org 2003; 19: 218-44.

[50] Dower J. Embracing defeat: Japan in the wake of World War II. New York: WW. Norton 1999.

[51] Varese F. The Russian mafia: private protection in a new market economy. Oxford: Oxford University Press 2001.

[52] Dixit A. Lawlessness and economics: alternative modes of governance. Princeton, NJ: Princeton University Press 2004

[53] Mokyr J. The lever of riches: technological creativity and economic progress. Oxford, UK: Oxford University Press 1990.

[54] Maddison A. Contours of the world economy 1-2030 AD: essays in macroeconomic history. Oxford, UK: Oxford University Press 2007.

[55] Maddison A. The world economy: volume 1: a millennial perspective; volume 2: historical statistics. New Delhi: Academic Foundation, by arrangement with OECD (Organization for Economic Co-operation \& Development) 2007.

[56] NAJD Online Academy. Saudi Arabia/Education 2010. Available from: http://www.alnujaidi.com/sa education.htm [Cited: 29 July 2010].

[57] Al-Suwaiyel MI. Kingdom of Saudi Arabia: toward a knowledgebased economy: 2008 Global Competitiveness Forum; 20-22 January; Riyadh 2008

[58] Al-Hargan A. Developing technology incubation models for the Arabic world: International Technology Incubation Forum 2009; Riyadh, Saudi Arabia 2009.

[59] Ministry of Information. Government/The Council of Oman 2009. Available from: http:/www.omanet.om/english/government/overvi ew.asp?cat=gov [Cited: 29 July 2010].

[60] Djankov S, Glaeser E, La Porta R, Lopez-de-Silanes F, Shleifer A. The new comparative economics. J Comp Econ 2003; 31: 595-619.
[61] BaumolWJ. Entrepreneurship, management and the structure of payoff. Cambridge, MA: MIT Press 1993.

[62] Abramovitz M. Catching up, forging ahead, and falling behind. J Econ Hist 1986; 66: 385-406.

[63] Lipset SM. Political man: the social basis of modern politics. New York: Doubleday 1960.

[64] Przeworski A. The last instance: are institutions the primary cause of economic development? Mimeo: New York University 2004.

[65] Przerworski A. Geography vs institutions revisited: were fortunes reversed? Mimeo: New York University 2004.

[66] The Economist. The tiger in front: a survey of India and China. 2005; March 5: 3-16.

[67] Meyer B, Lutz C, Wolter MI. Economic growth of the EU and Asia: a first forecast with the global econometric model GINFORS: 2004: 1st KEIO-UNU-JFIR Panel Meeting; Economic Development and Human Security: How to Improve Governance at the Inter-Governmental, Governmental and Private Sector Levels in Japan and Asia.Tokyo: 13-14 February; 2004.

[68] Lukáš M, Jan M. Application of econometric panel data model for regional competitiveness evaluation of selected EU 15 countries. J Competitiveness 2011; 4: 23-38

[69] Waczriarg R. Review of Easterly's the elusive quest for growth. J Econ Lit 2002; 40: 907-18.

[70] Easterly W. The elusive quest for growth: economists' adventures and misadventures in the tropics. Cambridge and London: MIT Press 2001.

[71] Solow RM. A contribution to the theory of economic growth. Quart J Econ 1956; 70: 65-94.

[72] Solow RM. Technical change and the aggregate production function. Rev Econ Stat 1957; 39: 312-20.

[73] Swan TW. Economic growth and capital accumulation. Econ Rec1956; 32: 334-61.

[74] Haines JD, Sharif NM. A framework for managing the sophistication of the components of technology for global competition.Competitiveness Rev 2006; 16: 106-21.

[75] Montesquieu C. The spirit of the laws. Paris 1748.

[76] Smith A. An inquiry into the nature and causes of the wealth of nations, Canaan E, Ed. Chicago, Illinois: University Chicago Press 1976.

[77] North DC, Thomas RP. The rise of the western world: a new economic history. Cambridge: Cambridge University Press 1973.

[78] Feser E, Ed. The Cambridge companion to Hayek. Cambridge: Cambridge University Press 2007.

[79] Hall RE, Jones CI. Why do some countries produce so much more output per worker than others? Quart J Econ 1999; 114: 83-116.

[80] DeLong JB,Shleifer A. Princes and merchants: city growth before the industrial revolution. J Law Econ 1993; 36: 671-702.

[81] Acemoglu D, Johnson S, Robinson JA. The colonial origins of comparative development: an empirical investigation. Am Econ Rev 2001; 91: 1369-401.

[82] Acemoglu D, Johnson S, Robinson JA. Reversal of fortune: geography and development in the making of the modern world income distribution. Quart J Econ 2002; 117: 1231-94.

[83] Easterly W, Levine R. Tropics, germs, and crops: how endowments influence economic development. J Mon Econ2003; 50: 3-39.

[84] Rodrik D, Subramanian A, Trebbi F. Institutions rule: the primacy of institutions over geography and integration in economic development. NBER Working Paper 9305, National Bureau of Economic Research (October) 2002.

[85] Alvarez M, Cheibub JA, Limongi F, Przeworski A. Democracy and development: political institutions and material well-being in the world, 1950-1990. Cambridge: Cambridge University Press 2000

[86] Mulligan C, Gil R, Sala-i-Martin X.Do democracies have different public policies than nondemocracies? J Econ Perspec 2004; 18: 5174 